\title{
THE EFFECT OF PROSTAGLANDINS $\mathrm{E}_{1}$ AND $\mathrm{F}_{2 \alpha}$ ON THE FERTILIZING ABILITY OF HAMSTER SPERMATOZOA
}

\author{
C. M. LUBICZ-NAWROCKI, S. K. SAKSENA AND M. G. CHANG \\ Worcester Foundation for Experimental Biology, Shrewsbury, \\ Massachusetts 01545, U.S.A.
}

(Received 25th fune 1973)

Prostaglandins are present in the male accessory glands (Goldblatt, 1933; von Euler, 1935; Mann, 1964; Bygdeman, Fredericsson, Svanborg \& Samuelsson, 1970), and can be synthesized by rat testis tissue (Ellis, 1972). Studies in sheep (McCracken, 1971; McCracken, Baird \& Goding, 1971) indicate that prostaglandins may be the naturally occurring luteolytic factor but the rôle of prostaglandins in male reproductive function has not been determined. Treatment of male rats and mice with prostaglandins $\mathrm{E}_{1}, \mathrm{E}_{2}$ and $\mathrm{F}_{2 \alpha}$ however, decreases the level of circulating (plasma) testosterone (Bartke, Musto, Caldwell \& Behrman, 1973; Saksena, El Safoury \& Bartke, 1973). Since mature hamster spermatozoa lose their fertilizing ability within 12 days after castration (LubiczNawrocki \& Glover, 1973), it seemed possible that administration of prostaglandins $\mathrm{E}_{1}$ or $\mathrm{F}_{2 \alpha}\left(\mathrm{PGE}_{1}\right.$ or $\left.\mathrm{PGF}_{2 \alpha}\right)$ might induce sterility by lowering the titre of plasma testosterone. The present paper reports on the fertilizing ability of male hamsters treated with $\mathrm{PGE}_{1}$ and $\mathrm{PGF}_{2 \alpha}$.

Adult male golden hamsters ( 125 to $145 \mathrm{~g}$ ) of known fertility were maintained under controlled conditions of temperature and lighting. Prostaglandins $\mathrm{E}_{1}$ and $\mathrm{F}_{2 \alpha}$ were dissolved in sterilized $0.9 \% \mathrm{NaCl}$ solution and refrigerated between injections. In order to test the effects of $\mathrm{PGE}_{1}$ and $\mathrm{PGF}_{2 \alpha}$ on the fertilizing ability of spermatozoa, six male hamsters were treated daily with $50 \mu \mathrm{gGE}_{1}$, and another group of six males received daily $50 \mu \mathrm{g} \mathrm{PGF}_{2 \alpha}$. Half of the daily dose was injected subcutaneously in $0.1 \mathrm{ml} / 100 \mathrm{~g}$ body weight at 08.30 hours and half at 20.30 hours. Three control animals were injected twice daily with $0.1 \mathrm{ml}$ sterilized $0.9 \% \mathrm{NaCl}$ solution. To test fertilizing ability, treated and control males were paired overnight with a female in oestrus; mating was confirmed by the presence of spermatozoa in the vagina and the females were killed approximately $40 \mathrm{hr}$ after mating. Eggs were flushed from the uterine tubes with $0.2 \mathrm{ml}$ Hanks' solution, mounted in toto (Chang, 1952) and examined with a phase contrast microscope for evidence of fertilization (the presence of a spermatozoon in the vitellus of a cleaved egg).

For the estimation of plasma testosterone, treated and control males were anaesthetized with sodium pentobarbitone (Nembutal; Abbott Laboratories) the morning after mating, approximately $12 \mathrm{hr}$ after the last injection of the prostaglandins. Blood was collected from the abdominal aorta into heparinized 
syringes and centrifuged immediately. Plasma samples were stored at $-20^{\circ} \mathrm{C}$ and testosterone was estimated by radioimmunoassay (Bartke, Steele, Musto \& Caldwell, 1973). The sensitivity of the assay was approximately 50 pg testosterone, and the values for the water blank were below $10 \mathrm{pg}$ testosterone. The levels of plasma testosterone were compared with those of fructose in the seminal vesicles, which were determined according to Lubicz-Nawrocki \& Glover (1973)

Table 1 shows that the fertilizing ability of spermatozoa was unaffected after 10 days of treatment of male hamsters with $\mathrm{PGE}_{1}$ or $\mathrm{PGF}_{2 \alpha}$, but $\mathrm{PGE}_{1}$ caused a significant decrease in plasma testosterone $(P<0.005)$. This suggests that fertilizing ability is not influenced by a decrease in plasma testosterone whereas previous work showed that fertilizing ability is androgen-dependent (LubiczNawrocki \& Glover, 1973). It seems, however, that after treatment with PGE the level of plasma testosterone remains high for at least 6 days when seminal vesicle fructose was similar to that in control animals (C. M. Lubicz-Nawrocki and S. K. Saksena, unpublished observations). Thus, treatment for longer than

Table 1. The effect of prostaglandins $E_{1}$ and $F_{2 \alpha}$ on plasma testosterone and fertilizing ability in intact male hamsters

\begin{tabular}{l|c|c|c|c|c|c}
\hline \multicolumn{1}{c|}{ Treatment } & $\begin{array}{c}\text { Dose } \\
(\mu \mathrm{g} / \text { day } \times 10)\end{array}$ & $\begin{array}{c}\text { Seminal vesicle } \\
\text { fructose } \\
(\mathrm{mg} / \mathrm{100} \mathrm{g} \text { dry wt }) \\
\text { Mean } \pm \text { S.E. }\end{array}$ & $\begin{array}{c}\text { Plasma } \\
\text { testosterone } \\
\text { females } \\
\text { Mean } \pm \text { S.E. }\end{array}$ & $\begin{array}{c}\text { No. of } \\
\text { females } \\
\text { mated } \dagger\end{array}$ & $\begin{array}{c}\text { Total } \\
\text { eggs } \\
\text { recovered }\end{array}$ & $\begin{array}{c}\% \\
\text { fertilization }\end{array}$ \\
\hline Saline (control) & 0 & $1 \cdot 86 \pm 0 \cdot 23$ & $3 \cdot 31 \pm 0 \cdot 75$ & 3 & 35 & 100 \\
Prostaglandin $\mathrm{E}_{1}$ & 50 & $1 \cdot 19 \pm 0 \cdot 19$ & $0 \cdot 63 \pm 0 \cdot 13^{* *}$ & 6 & 66 & 100 \\
Prostaglandin $\mathrm{F}_{2 \alpha}$ & 50 & $3 \cdot 12 \pm 0.50^{*}$ & $2 \cdot 67 \pm 0 \cdot 46$ & 6 & 64 & 100 \\
\hline
\end{tabular}

$* P<0.01 ; * * P<0.005 ;$ Student's $t$ test.

$\uparrow$ The number of males/group was the same as the number of females mated.

10 days might induce sterility since hamster spermatozoa retain normal fertilizing ability for 8 days after androgen withdrawal (Lubicz-Nawrocki \& Glover, 1973) although prolonged daily administration of $2 \mathrm{mg} \mathrm{PGE} \mathrm{P}_{2}$ or $\mathrm{PGF}_{2 \alpha}$ (which decrease plasma testosterone in rats: Saksena et al., 1973) did not affect the fertility of male rabbits (Hunt \& Nicholson, 1972). It is possible that after daily treatment of hamsters with $50 \mu \mathrm{g} \mathrm{PGE}_{1}$, the level of plasma testosterone is still sufficient to ensure the development of fertilizing ability and thereby maintain a supply of mature spermatozoa into the cauda epididymidis.

At all events, it seems that short-term treatment of hamsters with PGE $_{1}$ or $\mathrm{PGF}_{2 \alpha}$ does not affect fertilizing ability and is consistent with a recent report that such treatment does not influence the fertilizing ability of rat spermatozoa (Setty \& Kar, 1972).

This study was supported by the Ford Foundation through its Training Program in Physiology of Reproduction (S.K.S.) and by grants from the Ford Foundation and NIGHD (HD 03472) awarded to Dr M. G. Chang. The authors thank Mrs V. Kelleher for assistance. 


\section{REFERENGES}

Bartke, A., Musto, N., Caldwell, B. V. \& Behrman, H. R. (1973) Effect of cholesterol esterase inhibitor and of prostaglandin $F_{2 \alpha}$ on testis cholesterol and on plasma testosterone in mice. Prostaglandins, 3, 97.

Bartke, A., Steele, R. E., Musto, N. \& Caldwell, B. V. (1973) Fluctuations in plasma testosterone levels in adult male rats and mice. Endocrinology, 92, 1223.

Bygdeman, M., Fredericsson, B., Svanborg, K. \& Samuelsson, B. (1970) The relation between fertility and prostaglandin content of seminal fluid in man. Fert. Steril. 21, 622.

Chang, M. C. (1952) Fertilizability of rabbit ova and the effects of temperature in vitro on their subsequent fertilization and activation in vivo. J. exp. Zool. 121, 351.

ELLIs, L. C. (1972) Rat testicular prostaglandin synthesis and its relationship to androgen synthesis. Fedn Proc. Fedn Am. Socs. exp. Biol. 31, 295.

Goldblatt, M. W. (1933) A depressor substance in seminal fluid. F. Soc. chem. Ind., Lond. 52, 1056.

Hunt, W. L. \& Nrcholson, N. (1972) Studies on semen from rabbits injected with $\mathrm{H}^{3}$-thymidine and treated with prostaglandins $\mathrm{E}_{2}$ and $\mathrm{F}_{2 \alpha}$. Fert. Steril. 23, 763.

Lubicz-Nawrocki, G. M. \& Glover, T. D. (1973) The influence of the testis on the survival of spermatozoa in the cauda epididymidis of the golden hamster, Mesocricetus auratus. F. Reprod. Fert. 34, 315.

McGracken, J. A. (1971) Prostaglandin $\mathrm{F}_{2} \alpha$ and corpus luteum regression. Ann. N.Y. Acad. Sci. 180, 456.

MCGracken, J. A., Baird, D. T. \& Goding, J. R. (1971) Factors affecting the secretion of steroids from the transplanted ovary in sheep. Recent Progr. Horm. Res. 27, 537.

MANN, T. (1964) The biochemistry of semen and of the male reproductive tract, 2nd edn. Methuen, London.

Saksena, S. K., El Safoury, S. \& Bartke, A. (1973) Prostaglandins $E_{2}$ and $\mathbf{F}_{2 \alpha}$ decrease plasma testosterone levels in male rats. Prostaglandins, 4, 235.

Setty, B. S. \& KAR, A. B. (1972) Prostaglandins and 'functional' sterility in male rats. Curr. Sci. 41, 64. von Euler, U. S. (1935) A depressor substance in the vesicular gland. $\mathcal{F}$. Physiol., Lond. 84, 21. 